\title{
Legal perspective on development policies for sustainability of water in Malaysia
}

\begin{abstract}
Malaysia aims to be a developed state by 2020 . Various programs and policies towards this have been promulgated and development is rapidly arising as a result. Nevertheless, there is a vital need to balance development and sustainability of water resources in Malaysia. This is important as water demand is steadily increasing in the country's industrialized and highly populated cities. It is significant that water resources be managed efficiently and water conservation efforts such as rainwater harvesting be promoted across the country. This paper aims to examine development policies that may affect the sustainability of water resources and their implementation from the legal point of view. This doctrinal study involves analyses of related laws and development policies and their impact over the development process. The paper concludes that, although important laws and policies have been introduced, implementation has been hindered by lack of support from stakeholders and lack of integration between water agencies.
\end{abstract}

Keyword: Sustainable development; Water law and policies; Water resources management; Malaysia 